\title{
The Effect of Job Satisfaction and Perceived Organizational Support on Organizational Commitment of Banks' Employees in Padang
}

\author{
Muthia Roza Linda ${ }^{1}$, Riza Yonita ${ }^{2}$, \\ ${ }^{1}$ Universitas Negeri Padang, Padang and Indonesia, $\square$ muthia rozalinda@yahoo.com \\ ${ }^{2}$ Universitas Putra Indonesia"YPTK" Padang, Padang and Indonesia, $\square$ riza_yonita@yahoo.com
}

\begin{abstract}
This study aims to analyze: 1) to what extent job satisfaction affects the organizational commitment of banks' employees in Padang; and 2) to what extent perceived organizational support has an effect on the organizational commitment of banks' employees in Padang. This research is a causative research, which is a research that aims to see how far the independent variables affect the dependent variable. The population of this research is 100 banks' employees in Padang. The data were analyzed by using multiple linear regression to answer the hypothesis through t-test, and coefficient of determination $\left(R^{2}\right)$ is utilized with the help of SPSS version 24 to determine the effect of the independent variables. The results of this research indicate that: 1) job satisfaction has a positive and significant effect on the organizational commitment of banks' employees in Padang, and 2) perceived organizational support has a positive and significant effect on the organizational commitment of banks' employees in Padang. The $\mathrm{R}$ squared value is 0,530 , which means that both independent variables affect the independent variable up to $53 \%$, whereas the rest $47 \%$ is determined by other factors not examined in this research.
\end{abstract}

Keywords: the organizational commitment, job satisfaction, perceived organizational support

\section{Introduction}

The transformation of the business environment that tends to become more dynamic also affects the banking industry. Competition becomes increasingly tight with the entry of foreign banks that compete for customers in the same market. This is due to the fact that foreign banks have a number of advantages in terms of reputation, innovative product selection, and strong global network (Nina, 2009). The dynamics of competition are so tight in the banking industry sector, that it requires an early anticipation in the field of Human Resources (HR) to maintain the existence of the local company. Banks are included in high technology and high service companies; thus, the demand for excellent service becomes important in order to stay in the competitive field. Furthermore, the employees in the banking industry are also faced with a lot of workloads, which sometimes requires them to work on Saturdays and Sundays. Therefore, the issue of employee commitment becomes crucial for the banking industry.

Employees a high organizational commitment can become one of the assurances to maintain the continuity of the organization. Leininger (2008) reported that organizations that have highly committed employees will provide greater benefits to the organization. This is similar to what Robbins and Judge (2009) stated, that "committed employees will have little possibility to engage in matters that could harm the company due to a high sense of loyalty." This is mainly because the commitment of employees to the organization can be interpreted as an individual's psychological tie 
to the organization, which includes job involvement, loyalty and feelings of trust towards organizational values (Sopiah, 2008).

Results that remain consistent in the commitment literature show that a high degree of commitment will increase the positive outcomes for the organization (Mathiew and Jazac, 1990). Commitment is also one of the most important factors that can contribute to the achievement of organizational goals. Steers and Porter (1991) conclude that there are three factors that influence employees' commitment to the organization: 1) personal factors that include job satisfaction, psychological contract, job choice factors, and personal characteristics, and all of these factors will form an initial commitment; 2) organizational factors, which include initial works experiences, job scopes, supervision, and organizational goal consistency, which will shape or generate responsibility; and 3) non-organizational factor, which includes the availability of alternative jobs.

Mowday et al, (in Sopiah, 2008) identifies three forms of organizational commitment: 1) affective commitment, which relates to members' emotional connection to their organization, identification with the organization, and the members' involvement with activities within the organization; 2) normative commitment (moral commitment), which describes the feeling of attachment to continue working in the organization; and 3) continuance commitment (economical or qualitative commitment), which is associated with awareness of members of the organization to suffer losses if they leave the organization

Many factors can contribute to employees' commitment to the organization, and it is important to know what factors are causing or increasing the commitment of an employee. Van Dyne, Graham, and Dienesch (1994) mention several factors that influence one's organizational commitment based on a multidimensional approach: personal factors, situational factors, and positional factors. According to Argyis in Soetjipto (2007), factors that can affect the commitment of employees can come from the employees themselves (internal factors), such as motivation, job satisfaction, employee's skills/ability, and it can also come from outside of the employees (external factors), such as the atmosphere created in the work environment, the leadership style practiced on the subordinates, the benefits received, the relationship between colleagues, and so on.

Previous research has shown that job satisfaction, work expectation and personal characteristics have a positive effect on employees' commitment to the organization (Azeem, 2010, Malik, et al 2010, Schwepker, 2001 and Mulki et al, 2008). The research conducted by Pack (in Srimulyani, 2009) also suggests that perceived organizational support is positively related to employee' commitment to the organization.

Handoko (2011) further notes that employees who receive job satisfaction will do a better job. Employees who are usually satisfied with what they get from the company will give more than what is expected and will continue to improve their performance. On the contrary, employees with low job satisfaction tend to see work as tedious and boring, so that they work in a forced and careless manner. The problem of job satisfaction is also found in banks' employees in Padang. Due to high workload, banks' employees have to work an edition of 1-2 hours every day outside their usual working hours, and they even have to work overtime on Saturdays and Sundays. This often becomes a source of complaint for the employees and it triggers job stress. As a result, they strongly dislike their working hours and their frequent overtime work, which is not appreciated as an overtime work.

According to Luthans (2006), there are three dimensions that are generally accepted in job satisfaction. First, job satisfaction is an emotional response to the work situation. Second, job satisfaction is often determined according to how well the results meet or exceed expectations. If members of the organization feel that they are working too hard than others in the department, but they feel that they receive fewer rewards, then they may have a negative attitude towards their job, leadership, or coworkers because they are not satisfied. On the contrary, if they feel that they are treated well and paid properly, then they will have a positive attitude towards their work, since they feel satisfied. Third, job satisfaction represents some related attitudes in which employees have 
affective responses, among which: the job itself, salary, promotion opportunities, supervision, and coworkers.

Job satisfaction can be measured from a variety of dimensions, which includes the satisfaction in the job itself, salary, recognition, the relationship between supervisors with employees, and opportunities to move forward. Each dimension produces a feeling of overall satisfaction with the work itself. Meanwhile, Robbins \& Judge (2009) mention 5 factors that support job satisfaction, namely works that is mentally challenging, appropriate compensation, supportive working conditions, support co-workers, and the suitability of employees' personality with the job.

Perceived Organizational Support (POS) refers to employees' perceptions of the extent to which the organization assesses employees' contributions and cares about employees' well-being. Perceived organizational support also refers to the overall employee's beliefs on the extent to which companies value employees, care about their well-being, and support the social-emotional needs of employees by providing resources to help employees (Rhoades \& Eiseberger, 2002). High perceived organizational support generally tends to lower employees' desire to leave the organization. One the the employees' way to pay respect to the organization whenever they feel rewarded is through continued participation, which will lead to a feeling of organizational membership as an important part of the employee's self-identity (Eisenberger et al., 2001).

Rhoades and Eisenberger (2002) recommend 8 items to measure the level of organizational support, which includes: the organization appreciates the contribution of employees, the organization appreciates the extra effort the employee has given, the organization notices all employee complaints, the organization is very concerned about the welfare of the employees, the organization will help employees if they do not do a good job, the organization is concerned with the general satisfaction of employees' work, the organization is attentive to employees' concern, and the organization is proud of the employee's success at work.

Based on the descriptions above, The hypothesis of this research area:

H1: Job satisfaction has a positive effect on organizational commitment of banks' employees in Padang.

H2: Perceived organizational support has a positive effect on organizational commitment of banks' employees in Padang.

\section{Methods}

The type of research conducted by the author is included in the causative research, which is a study that aims to determine the effect of job satisfaction and perceived organizational support - as independent variable - on the employees' organizational commitment, which poses as a dependent variable. The object of research is employees in banks in Padang, where the number is unknown. The sampling was conducted with the consideration that the population is quite large that it is not possible to examine all existing data, as it requires a lot of time, cost, and energy. Therefore, this study uses only a part of the overall research object called the sample, with the number of samples in this study as many as 100 people. The data analysis technique used multiple linear regression analysis using SPSS version 24.0.

\section{Operational Definition of Variables}

To give an explanation about research variables used, the following formula explains the operational definition of each variable in this study: 
Table 1. Research Variables and Measurement Indicators

\begin{tabular}{|c|c|c|c|}
\hline No & Variables & Indicators & Sources \\
\hline 1. & $\begin{array}{l}\text { Organizational } \\
\text { Commitment }\end{array}$ & $\begin{array}{ll}\text { a. } & \text { Affective Commitment } \\
\text { b. Normative Commitment } \\
\text { c. }\end{array}$ & $\begin{array}{l}\text { Mowday et al, } \\
1982 \text { (in Sopiah, } \\
\text { 2008) }\end{array}$ \\
\hline 2. & Job Satisfaction & $\begin{array}{ll}\text { a. A challenging job } \\
\text { b. Rewards } \\
\text { c. Working conditions } \\
\text { d. Co-workers } \\
\text { e. Suitability of personality with work }\end{array}$ & Robbins (2009) \\
\hline 3. & $\begin{array}{l}\text { Perceived } \\
\text { Organizational } \\
\text { Support }\end{array}$ & $\begin{array}{l}\text { a. The organization values employees' } \\
\text { contributions } \\
\text { b. The organization appreciates the extra } \\
\text { effort that employees have provided } \\
\text { c. The organization pays attention to all } \\
\text { employee complaints } \\
\text { d. The organization is very concerned about } \\
\text { the welfare of employees } \\
\text { e. The organization will help employees if } \\
\text { they do not do a good job } \\
\text { f. The organization is attentive to } \\
\text { employees' concern. }\end{array}$ & $\begin{array}{l}\text { Rhoades and } \\
\text { Eisenberger } \\
(2002)\end{array}$ \\
\hline
\end{tabular}

\section{Results and Discussions}

To find out the regression coefficient of each independent variable and the direction of the influence on the dependent variable, the analysis of multiple regression data obtained by using SPSS program version 24 is shown in the following table:

Table 2. Multiple Linear Regression Results of Research Variables

\begin{tabular}{|c|c|c|c|c|c|c|}
\hline \multicolumn{2}{|c|}{ Model } & \multicolumn{2}{|c|}{$\begin{array}{c}\text { Unstandardized } \\
\text { Coefficients }\end{array}$} & \multirow{2}{*}{$\begin{array}{c}\begin{array}{c}\text { Standardized } \\
\text { Coefficients }\end{array} \\
\text { Beta }\end{array}$} & \multirow[t]{2}{*}{$\mathrm{t}$} & \multirow[t]{2}{*}{ Sig. } \\
\hline & & B & $\begin{array}{l}\text { Std. } \\
\text { Error }\end{array}$ & & & \\
\hline \multirow[t]{3}{*}{1} & (Constant) & 0,326 & 0,339 & & 0,964 & 0,338 \\
\hline & Support & 0,593 & 0,087 & 0,563 & 6,822 & 0,000 \\
\hline & Satisfaction & 0,265 & 0,088 & 0,249 & 3,016 & 0,003 \\
\hline
\end{tabular}

a. Dependent Variable: Commitment

Source : Results of processed primary data (2018)

Based on regression results from Table 2 above, it can be determined that the multiple linear regression equation of this study is as follows:

$\mathrm{Y}=0.326+0.265 \mathrm{X} 1+0,593 \mathrm{X} 2$

In which:

Y: Organizational Commitment

X1: Job Satisfaction

X2: Organizational Support 
Interpretation of the regression equation obtained is as follows:

1) The constant value is 0.326 with a positive sign, which means that even without job satisfaction and organizational support perceived by employees in carrying out their work, employees still have a positive organizational commitment to the organization of the company where they work.

2) The job satisfaction regression coefficient (X1) is 0.265 and of positive sign, which indicates that the more job satisfaction felt by employees in carrying out their work, then the organizational commitment of employees to the company will also increase.

3) The coefficient of regression of organizational support (X2) is 0,593 and marked as positive, which indicates that the higher the perceived organizational support of the employee, the more the organizational commitment of employees to the company will increase.

\section{Hypothesis Test (t-test)}

1) From the data obtained, job satisfaction (X1) has a positive and significant effect on organizational commitment $(Y)$ of banks' employees in Padang. Based on table 2, the t-count value is 3,016, in which the value ni is greater than the $t$-table of 1.661 with the sig. value of $0.003<0.05$. This means that Ho is rejected and Ha is accepted. Thus, it can be concluded that the first hypothesis of this study is accepted, which states that job satisfaction has a positive and significant impact on organizational commitment.

2) Based on the data processed, it is obtained that perceived organizational support (X2) has a positive and significant effect on organizational commitment $(\mathrm{Y})$ banks' employees in Padang. Based on Table 2, the t-count value is 6,822 and this value is bigger than the $t$-table, which is 1,661 with a sig. value of $0,000<0.05$. This means that Ho is rejected and Ha is accepted. Therefore, it is concluded that the second hypothesis in this study is accepted, in which organizational support has a positive and significant impact on organizational commitment.

\section{Coefficient of Determination}

To find out the effect of independent variables, which consist of job satisfaction and organizational support, on the organizational commitment of banks' employees in Padang, the value of adjusted $\mathrm{R}$ square is shown in the table below.

\begin{tabular}{|c|c|c|c|c|}
\hline Model & $\mathrm{R}$ & $\begin{array}{c}\mathrm{R} \\
\text { Square }\end{array}$ & $\begin{array}{l}\text { Adjusted } \\
\text { R Square }\end{array}$ & $\begin{array}{l}\text { Std. Error of } \\
\text { the Estimate }\end{array}$ \\
\hline 1 & ,728a & 0,530 & 0,521 & 0,47035 \\
\hline \multicolumn{5}{|c|}{ a. Predictors: (Constant), Satisfaction, Support } \\
\hline \multicolumn{5}{|c|}{ b. Dependent Variable: Commitment } \\
\hline
\end{tabular}

Source : Results of processed primary data (2018)

As shown in Table 3 above, the $\mathrm{R}$ squared value is 0,530, which indicates that the effect of independent variables, consisting of job satisfaction and organizational support, on the dependent variable, that is the organizational commitment, is equal to $53 \%$. The rest $47 \%$ is determined by other factors not examined in this research.

\section{The First Hypothesis (The Effect of Job Satisfaction on Organizational Commitment)}

Hasibuan (2002) mentions that satisfaction is a pleasant emotional attitude and an act of loving the work either inside/outside the work scope or a combination of inside and outside work scope. This attitude is reflected in the work ethics, discipline and work performance. High satisfaction will result in a better relationship between employees in the organization, and this too will affect the quality of commitment among employees (Zineldin and Johnson, 2000). Job satisfaction will motivate employees to further increase their commitment to the company and their work productivity. 
Based on the results of data analysis, it is found that the sig. value of job satisfaction's effect on employees' organizational commitment is of 0.000 . Due to sig. value of $0.000<0.05$, it is concluded that the first hypothesis of research, that job satisfaction has a positive and significant impact on organizational commitment, is accepted. This is similar to the opinion of Mathis (2006), who states that job satisfaction is an interesting and important aspect, as he found that the most fundamental finding is the effect of job satisfaction on employee commitment. If the workforce is committed to the organization, then they will become more productive. People who are relatively satisfied with their work will be more committed to the organization, and people who are committed to the organization are more likely to gain greater satisfaction. The results of this study are in line with research conducted by Muhammed and Eleswed (2013), that job satisfaction has a positive and significant impact on organizational commitment.

\section{The Second Hypothesis (The Effect of Perceived Organizational Support on Organizational Commitment)}

Perceiced organizational support is something employees perceive as emotional-social needs, and it indicates the readiness of the organization to appreciate employees' work improvement and a trend in providing help when employees need to do an effective job (Fuller et al., 2003). Perceived organizational support refers to employees' perceptions of the extent to which organizations value their employees' contributions, support, and well-being (Rhoades \& Eisenberger, 2002). Various research has found that in most organizations, employees who feel that they have the support of the organization will have a sense of meaningfulness, which will increase their commitment. It is this commitment that ultimately encourages employees to try to help the organization to achieve its goals, and this will increase their expectation that work performance will be noticed and appreciated by the organization (Rhoades \& Eisenberger, 2002).

Based on the results of data analysis, it is found that the sig. value of perceived organizational support's effect on employees' organizational commitment shows a value of 0.003 . With the sig. value of $0.003<0.05$, it is concluded that the second hypothesis of research, that the perceived organizational support has a positive and significant impact on organizational commitment, is accepted. Based on the results of this study, it is important for the company to continue to improve the perceived organization support for its employees. This statement is in line with Tumwesigye (2010) who states that organizational commitment can be created because of the perception of employees' support. Organizational support is one of the keys to building employee commitment. Similar research conducted by Gupta et al. (2010) found that the perceived organizational support has a positive effect on organizational commitment, and the employees' perception of organization support results in employees' belief on the organization value and it affects their contribution to the organization.

\section{Conclusions}

Based on the results and discussion, the conclusions of this study are:

1. job satisfaction $(\mathrm{X} 1)$ has a positive and significant effect on organizational commitment $(\mathrm{Y})$ of banks' employees in Padang.

2. Perceived organizational support (X2) has a positive and significant effect on organizational commitment (Y) banks' employees in Padang.

\section{Acknowledgments}

We would like to thanks to Faculty of Economic, Universitas Negeri Padang which has funded this research and all those involved in the completion of the research 


\section{References}

Eisenberger, R.; Armeli, S.; Rexwinkel, B.; Lynch, P.D.; dan Rhoades, L. (2001). Reciprocation of perceived organizational support. Journal of Applied Psychology, 86 (1): $42-51$

Fuller, B., Brnet, T., Hester, K., and Relyea, C. (2003). A social idenity perspective on the relationship between perceived organizational support and prganizational commitment. Journal of Social Psychology. 143 (6).

Gupta-Aggarwal, Meenakshi., NeharikaVohra., and Depti Bhatnagar. (2010). Perceived organizational support and organizational commitment: the mediational influence of psychological well-being. Journal of Business and Management ,16 (2).

Handoko, Hani T. (2011). Manajemen Sumber Daya Manusia. Yogyakarta : BPFE Yogyakarta.

Hasibuan, Malayu S.P. (2002). Manajemen Sumber Daya Manusia. Bumi Aksara. Jakarta

Leininger, J. (2008). The key to retention: commited employees, http://www.mekonginsight.com//?p=556. Diakses 28 September 2017

Luthans, Fred. 2006. Perilaku Organisasi. Edisi 10. Yogyakarta: ANDI

Mathieu, I., \& Zajac, D. (1990). A review and meta-analysis of the antecedents, correlates, and consequences of organizational commitment. Psychological Bulletin, Vol. 108, pp. 171-194.

Mathis, R.L. \& Jackson, J.H. (2006). Human Resource Management. 10th ed. Jakarta: Salemba Empat.

Mohammed, Fatema., dan Eleswed, Muath. (2013). Job satisfaction and organizational commitment: a correlational study in Bahrain. International Journal of Business, Humanities and Technology. Vol.3, No.5.

Nina Sakina. (2009). Komitmen organisasi karyawan pada PT.Bank "X" Di Jakarta. Jurnal Psikologi Vol 7 No 2. 81-90.

Rhoades, Linda. \& Eisenberger, Robert. (2002). Perceived organizational support: a review of the literature. Journal of Applied Psychology, Vol 87, No. 4, 698-714.

Robbins, Stephen P. Dan Judge, TImothy A. (2009). Organizational Behviour. 13 $3^{\text {th }}$ Edition. Pearson Education, Inc., Upper Saddle River, New Jersey.

Sopiah. (2008). Perilaku Organisasional. Yogyakarta : Penerbit Andi.

Srimulyani, V.A. (2009). Tipologi dan anteseden komitmen organisasi. Jurnal Ilmiah Widya Wana. 33 (1), 31-37.

Steers \& Porter. 1991. Motivation and Work Behavior. 5th Ed. USA: McGraw - Hill Book Co

Tumwesigye, G. (2010). The relationship between perceived organizational support and turnover intentions in a developing country: The mediating role of organisational commitment. African Journal of Business Management, 4(6), 942-952.

Van Dyne, L., Graham, J. W., \& Dienesch, R. M. (1994). Organizational citizenship behavior: construct redefinition, measurement, and validation. Academy of Management Journal, 37, 765-802.

Zineldin, Mosad and Johnson, Patrick. (2000). An examination of the main factors affecting trust/commitment in supplier-dealer relationship: an empirical study of the Swedish wood industry. TQM Magazine. Vol. 12 Iss:4 p.245 